\title{
University of Illinois at Urbana-Champaign
}

From the SelectedWorks of Don Fullerton

May, 1991

\section{The Irrelevance of Detail in a Computable General Equilibrium Model}

Tyler Fox

Don Fullerton, University of Illinois at Urbana-Champaign 


\title{
The irrelevance of detail in a computable general equilibrium model *
}

\author{
Tyler Fox and Don Fullerton \\ University of Virginia, Charlottesville, VA 22901, USA \\ Received 9 October, 1990 \\ Accepted 7 December 1990
}

\begin{abstract}
We eliminate many complicated features of a computable general equilibrium model, and reevaluate several reforms of capital taxation. Results of the simple model are surprisingly similar. Welfare gains depend more on a key unknown elasticity than on all the additional modeling complications combined.
\end{abstract}

\section{Introduction}

In 1981, Fullerton, King, Shoven, and Whalley (henceforth, FKSW) unveiled a complicated computable general equilibrium model of the United States economy and tax system. The detailed specification in this model was designed and used to simulate the capital allocation and efficiency effects of several specific corporate tax policy proposals. However, this modeling detail was obtained at the expense of considerable effort from several researchers over several years. A major question is whether the detail of such a model is worth the inevitable costs.

To address this question, we construct a simplified model that includes only the essential elements of the larger model. We discuss what detail is relevant to the problem at hand [a general discussion of the choice between issue-specific and general-purpose models is in Shoven and Whalley (1984, p. 1046)]. For this capital allocation problem, we find that the welfare results of the simple model are surprisingly similar to those of the complex FKSW model [as fully described and updated in the book by Ballard, Fullerton, Shoven, and Whalley (henceforth BFSW, 1985)]. Moreover, those authors performed only limited sensitivity analysis. We vary the elasticity of substitution between labor and capital in the simple model and show that results depend more on the value of this single parameter than on the many complex features omitted.

The next section specifies the basic design of the simple model. Section 3 reviews the differences between the two models, specifically the details missing in the simple model. Section 4 presents the welfare results of each model for comparison.

\section{The simple model}

Obviously we would need consumer detail to obtain distributional results, savings behavior to obtain dynamic results, or labor supply behavior to consider wage tax changes. For the comparative

\footnotetext{
* We are grateful for helpful suggestions from Charles Ballard and Jon Skinner.
} 
static simulation of capital reallocation considered here, however, none of these complications is particularly necessary. As suggested in the partial equilibrium formula of Harberger (1966), the most relevant detail in this case includes the initial use of factors, effective tax rates, and the elasticity of substitution in production. Also, Shoven (1976) shows that industry disaggregation has an effect. We design the simple model accordingly.

The production side of the simple model identifies eighteen industries, where each produces a single output from a combination of capital and labor according to a constant elasticity of substitution (CES) production function. Initial quantities of each factor are taken directly from BFSW (1985, pp. 59-60). Each factor is assumed homogeneous and mobile among industries, and total endowments are fixed.

The production side of the simple model also incorporates effective tax rates directly from tables in BFSW (1985, pp. 59, 73, and 83). The corporation income tax, the corporate franchise tax, and the property tax are all treated as ad valorem taxes on capital services by industry. Social Security payroll taxes, workmen's compensation, and unemployment compensation taxes are treated as ad valorem taxes on the use of labor services by industry. Finally, sales and excise taxes are treated as ad valorem taxes on consumer purchases of the eighteen producer goods.

The consumption side of the simple model has only one consumer with a Cobb-Douglas utility function defined over the eighteen goods. The consumer maximizes utility subject to income, which includes the equilibrium returns to endowments of labor and capital. The government sector collects revenue from the capital, labor, and sales taxes and returns this entire amount to the consumer in the form of a lump-sum transfer. An equal yield feature maintains the size of the government when each new tax regime is evaluated.

To obtain parameters, backward solution techniques are used in the same manner as BFSW for their 1973 benchmark data set. The elasticities of substitution for the eighteen industries are taken from a table in the BFSW book (p. 134). The Kimbell--Harrison (1986) factor price revision rule is used to compute equilibria.

\section{Differences between the models}

The detailed specifications of the BFSW model that are not included in the simple model are:

(1) twelve consumer groups defined by annual income level, from tax return data, with different cndowments of labor and capital,

(2) value-added as a CES function of labor and capital, with intermediate inputs described by a conventional fixed-coefficient input/output matrix,

(3) conversion of the eighteen producer goods into fifteen consumer goods, achieved through an additional fixed-coefficient matrix,

(4) an additional industry for government enterprises, as well as a general government that acts like a consumer with Cobb-Douglas preferences over the eighteen goods,

(5) other taxes and transfers, including a linear personal income tax for each consumer group with its own marginal tax rate,

(6) a foreign sector which generates a difference between the demands of U.S. consumers and the demands facing U.S. producers,

(7) investment/saving decisions, in which consumer savings are converted into derived demands for producer goods by means of a composite saving-investment commodity, and

(8) a labor-leisure decision on the part of each consumer group. 


\section{Results}

We calculate static general equilibrium resource allocation effects for six capital tax policy proposals, including:

(1) equalization of capital tax rates across industries,

(2) full integration of corporate and personal taxes with indexing for inflation,

(3) full integration without indexing,

(4) dividend deduction from corporate income tax,

(5) dividend deduction from personal income tax, and

(6) dividend gross-up and credit.

These plans are fully described on pp. 155-157 of BFSW, and each results in a new vector of capital tax rates by industry. We simulate the effects of each tax change and compare the results of the BFSW model, the simple CES model, and an even simpler Cobb-Douglas model. In addition, we examine the sensitivity of estimates to changes in the elasticity of substitution between labor and capital.

Table 1 shows the increase in real national income, in billions of 1973 dollars, calculated as the geometric mean of the Paasche and Laspeyres indices. This measure was used in the original paper by Fullerton, King, Shoven, and Whalley, as updated in the BFSW book (1981, p. 160). Results from the simple model are surprisingly close to those of the BFSW model, ranging from 5 percent high (plan 4) to 27 percent low (plan 5).

Table 1

Static welfare effects and their sensitivity to changes in the elasticity of substitution between capital and labor.

\begin{tabular}{|c|c|c|c|c|c|}
\hline \multirow[t]{3}{*}{ Plan } & \multicolumn{5}{|c|}{ Lump-sum scaling ${ }^{a}$} \\
\hline & \multirow[t]{2}{*}{$\begin{array}{l}\text { BFSW } \\
\text { model }^{b}\end{array}$} & \multirow{2}{*}{$\begin{array}{l}\text { Simple } \\
\text { CES } \\
\text { model }^{c}\end{array}$} & \multicolumn{3}{|c|}{$\begin{array}{l}\text { Simple CES model } \\
\text { Elasticity of substitution }\end{array}$} \\
\hline & & & 0.5 & 1.0 & 1.5 \\
\hline $\begin{array}{l}\text { (1) Equal capital tax } \\
\text { rates on industry }\end{array}$ & 10.912 & 10.183 & 6.781 & 11.479 & 16.893 \\
\hline $\begin{array}{l}\text { (2) Full integration } \\
\text { with indexing }\end{array}$ & 9.671 & 7.367 & 4.829 & 8.372 & 11.817 \\
\hline $\begin{array}{l}\text { (3) Full integration } \\
\text { without indexing }\end{array}$ & 7.855 & 6.989 & 4.543 & 8.010 & 11.484 \\
\hline $\begin{array}{l}\text { (4) Dividend deduction from } \\
\text { corporate income tax }\end{array}$ & 3.580 & 3.777 & 2.483 & 4.342 & 6.087 \\
\hline $\begin{array}{l}\text { (5) Dividend deduction from } \\
\text { personal income tax }\end{array}$ & 4.068 & 2.986 & 1.885 & 3.419 & 5.066 \\
\hline $\begin{array}{l}\text { (6) Dividend gross-up } \\
\text { and credit }\end{array}$ & 3.450 & 2.647 & 1.646 & 3.052 & 4.582 \\
\hline
\end{tabular}

${ }^{a}$ Revenue is replaced by a lump-sum tax on the consumer's income. The figures in the table are the geometric mean of Paasche and Laspeyres measures of the change in annual real expanded national income (in billions of 1973 dollars).

b This column of static welfare effects is taken from Table 8.1 of Ballard, Fullerton, Shoven, and Whalley (1985, p. 160).

c This column is from simulations using particular elasticities of factor substitution for each industry [BFSW (1985, p. 134)], which vary from 0.676 to 1.0 .

"Each of these three columns uses the same elasticity of substitution in all industries. 
With full integration in the simple model (plan 2), seven industries use less capital than in the benchmark. Some 7.1 percent of the total capital stock is reallocated from these seven industries to the other eleven industries. In the BFSW model, six of these same seven industries use less capital, and 6.5 percent of total capital is reallocated (1985, p. 159).

Neither FKSW nor BFSW tested the sensitivity of their welfare estimates to changes in the elasticities of substitution between labor and capital. Table 1 displays welfare effects for the simple CES model with the elasticity of substitution for all industries set to $0.5,1.0$ (the Cobb-Douglas case), and 1.5. These changes are shown to have a large impact on the magnitude of the welfare effect. In fact, the Cobb-Douglas case better approximates the welfare estimates of the BFSW model than does the simple CES model. The range of differences for the Cobb-Douglas case is plus 21 percent to minus 16 percent from BFSW results.

The magnitude of the welfare effect increases for higher assumed values of the elasticity. For example, the welfare estimate under plan 2 more than doubles, from $\$ 4.829$ billion to $\$ 11.817$ billion. This sensitivity analysis has shown that the assumed value of this elasticity has greater impact on the results of the policy simulations than all of the additional modeling complications combined.

This note sheds light on the necessity of complex modeling techniques in computable general equilibrium models. Considering the high cost of the complexities, one must ask which features of a proposed model are likely to have important impact on the results. Simplicity should be a goal of such models, with other features added only where there is reason to believe they will make a difference. Furthermore, careful attention should be given to the specification of elasticity estimates used in these models.

\section{References}

Ballard, Charles L., Fullerton, Don, Shoven, John B., and John Whalley, 1985, A general equilibrium model for tax policy evaluation, (University of Chicago Press, Chicago, IL).

Fullerton, Don, King, A. Thomas, Shoven, John B., and John Whalley, 1981, Corporate tax integration in the United States: A general equilibrium approach, American Economic Review 71, Sept. 677-691.

Harberger, Arnold C., 1966, Efficiency effects of taxes on income from capital, in: M. Krzyzaniak, ed., Effects of corporation income tax (Wayne State University Press, Detroit, IL).

Kimbell, Larry J., and Glenn W. Harrison, 1986, On the solution of general equilibrium models, Economic Modelling 3, July, $197-212$.

Shoven, John B., 1976, The incidence and efficiency effects of taxes on income from capital, Journal of Political Economy 84. Dec. $1261-1283$

Shoven, John B. and John Whalley, 1984, Applied general-equilibrium models of taxation and international trade: An introduction and survey, Journal of Economic Literature 22, Sept. 1007-1051. 